\title{
Role of Synadenium grantii latex proteases in nematicidal activity on Meloidogyne incognita and Panagrellus redivivus
}

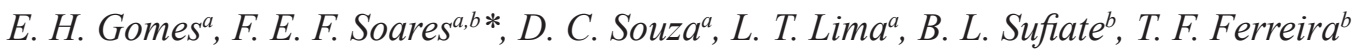 \\ and J. H. Queiroz ${ }^{b}$ \\ aUniversidade do Estado de Minas Gerais - UEMG, Av. Olegário Maciel, 1427, Bairro Industrial, \\ CEP 36500-000, Ubá, MG, Brasil \\ ${ }^{\text {b} D e p a r t a m e n t o ~ d e ~ B i o q u i ́ m i c a ~ e ~ B i o l o g i a ~ M o l e c u l a r, ~ U n i v e r s i d a d e ~ F e d e r a l ~ d e ~ V i c ̧ o s a ~-~ U F V, ~}$ \\ Av. Peter Henry Rolfs, s/n, CCBII, Campus Universitário, CEP 36570-900, Viçosa, MG, Brasil \\ *e-mail: filippeufv@yahoo.com.br
}

Received: November 21, 2017 - Accepted: March 15, 2018 - Distributed: November 30, 2019

(with 2 figures)

\begin{abstract}
Synadenium grantii is a Euphorbiaceae plant commonly found in Brazil, known as Janaúba or Leitosinha, whose latex is traditionally used for several purposes. However, it is not known whether the nematicidal action of this plant latex occurs due to the action of proteases. The present work aims to evaluate the nematicidal activity of proteases from Synadenium grantii latex on Meloidogyne incognita and Panagrellus redivivus. S. grantii latex used in the present study was collected from specimens found in Universidade Federal de Viçosa, Viçosa, Minas Gerais, Brazil. The drained latex was collected in Eppendorf microtubes and immediately stored on ice at $4{ }^{\circ} \mathrm{C}$. After this extraction, the latex was frozen $\left(-20^{\circ} \mathrm{C}\right)$ during 2 hours, thawed at room temperature $\left(25^{\circ} \mathrm{C}\right)$ and centrifuged at $10,000 \mathrm{~g}$ at $4{ }^{\circ} \mathrm{C}$ for 30 minutes to remove larger particles and concentrate the proteases. After the centrifugation, assays of enzymatic activity were performed in order to know in which of the phases the enzymes were found. S. grantii latex presented protease, but no chitinase activity. The results show that there was a significant difference $(\mathrm{p}<0.01)$ between the treated and control groups, with 100\% mortality of Meloidogyne incognita and 72\% average mortality of Panagrellus redivivus. In addition, it was demonstrated that the nematicidal action occurred due to the action of the proteases, since the control was only differentiated from the treatment by the presence of the enzymes with biological activity.
\end{abstract}

Keywords: Synadenium grantii, protease, Panagrellus redivivus, Meloidogyne incognita.

\section{Papel das proteases do látex de Synadenium grantii na atividade nematicida sobre Meloidogyne incognita e Panagrellus redivivus}

\section{Resumo}

Synadenium grantii é uma planta Euphorbiaceae comumente encontrada no Brasil, conhecida como Janaúba ou Leitosinha, e tem seu látex usado tradicionalmente para diferentes propósitos. Entretanto, não se conhece se a atividade nematicida da planta ocorre devido à ação de proteases. O presente trabalho tem como objetivo avaliar a atividade nematicida das proteases do látex de Synadenium grantii sobre Meloidogyne incognita e Panagrellus redivivus. O látex de $S$. grantii utilizado no presente trabalho foi coletado a partir de espécimes encontradas na Universidade Federal de Viçosa, Viçosa, Minas Gerais, Brazil. O látex foi coletado em microtubos Eppendorf e imediatamente armazenado em gelo a $4{ }^{\circ} \mathrm{C}$. Após esta extração, o látex foi congelado $\left(-20^{\circ} \mathrm{C}\right)$ durante 2 horas, descongelado à temperatura ambiente $\left(25^{\circ} \mathrm{C}\right)$ e centrifugado a $10000 \mathrm{~g}$ a $4{ }^{\circ} \mathrm{C}$ durante 30 minutos para a remoção de partículas e concentração das proteases. Após a centrifugação, foram realizados ensaios de atividade enzimática para saber em qual das fases as enzimas foram encontradas. O látex de S. grantii apresentou atividade de protease, mas nenhuma atividade de quitinase. Os resultados mostram que houve diferença significativa $(\mathrm{p}<0,01)$ entre os grupos tratados e controle, com $100 \%$ de mortalidade de Meloidogyne incognita e $72 \%$ de mortalidade média de Panagrellus redivivus. Além disso, foi demonstrado que a ação nematicida ocorreu devido à ação das proteases, uma vez que o grupo controle só foi diferenciado do tratamento pela presença das enzimas com atividade biológica.

Palavras-chave: Synadenium grantii, protease, Panagrellus redivivus, Meloidogyne incognita. 


\section{Introduction}

Synadenium grantii is a Euphorbiaceae plant commonly found in Brazil. It is known as Janaúba or Leitosinha, whose latex is traditionally used for injuries, wound healing, treatment of gastric diseases and nematode infections (Munhoz et al., 2014). Plant latex is a viscous fluid and colloidal in nature, which contains proteins, alkaloids, tannins, terpens, starch, sugars, oils, resins, gums and enzymes (Domsalla and Melzig, 2008; Upadhyay, 2011; Araújo et al., 2017; Benmerache et al., 2017). Enzymes, specifically proteases and chitinases, produced by fungi and found in plants latex have nematicidal activity reported by several authors (Soares et al., 2015; Stepek et al., 2007; Sufiate et al., 2017a, b).

Nematodes from Meloidogyne genus are known as root-knot nematodes. They parasite several plants economically important, causing annually a billions dollars loss (Agrios, 2005). These parasites are usually combated by use of pesticides, however there is a worldwide trend to stop using these compounds, since they are highly harmful to animal and human health and to the environment (Brand et al., 2010). In this way, the use of plant enzymes appears as a promising alternative method for phytonematodes control.

The free-living nematodes from Panagrellus genus are used as experimental model in researches involving compounds with nematicidal activity, due their easy cultivation, short life cycle and for their high motility in water, which allows sublethal toxic effects to be observed more easily in nematodes from this genus than in phytonematodes (Kwok et al., 1992).

Like other plant latex, $S$. grantii latex is also rich in proteolytic enzymes. Some of these enzymes have been purified and characterized (Menon et al., 2002; Rajesh et al., 2006). However, it is not known whether the nematicidal action of this plant latex occurs due to the action of the proteases. Thus, the present work aims to evaluate the nematicidal activity of proteases from $S$. grantii latex on Panagrellus redivivus and Meloidogyne incognita.

\section{Material and Methods}

\subsection{Latex}

S. grantii latex used in the present study was collected from specimens found in Universidade Federal de Viçosa, Viçosa, Minas Gerais, Brazil. To obtain the latex, superficial cuts were made on the plant stem. The drained latex was collected in Eppendorf microtubes and immediately stored on ice at $4{ }^{\circ} \mathrm{C}$. After this extraction, the latex was frozen $\left(-20{ }^{\circ} \mathrm{C}\right)$ during 2 hours, thawed at room temperature $\left(25^{\circ} \mathrm{C}\right)$ and centrifuged at $10,000 \mathrm{~g}$ at $4{ }^{\circ} \mathrm{C}$ for 30 minutes to remove larger particles and concentrate the proteases. After the centrifugation, assays of enzymatic activity were performed in order to know in which of the phases the enzymes were found.

\subsection{Enzyme assays}

In order to verify the presence and measure the protease and chitinase activities, the modified assays from Braga et al. (2015) were used. Measurement of protease activity was performed in microtubes, using $480 \mu \mathrm{L}$ citrate phosphate buffer $100 \mathrm{mM} \mathrm{pH} \mathrm{6.0,500} \mu \mathrm{L}$ casein $1 \%(\mathrm{w} / \mathrm{v})$ and $20 \mu \mathrm{L}$ of sample. The reagents were incubated at $50{ }^{\circ} \mathrm{C}$ for 10 minutes. After this period, the reaction was stopped by adding $1 \mathrm{~mL}$ of trichloroacetic acid $10 \%(\mathrm{w} / \mathrm{v})$, the microtubes were centrifuged at $10,000 \mathrm{~g}$ at $4{ }^{\circ} \mathrm{C}$ for 15 minutes, the supernatants were collected and the absorbance readings were performed at $280 \mathrm{~nm}$ with the aid of a spectrophotometer. Chitinase activity was measured in test tubes, using $150 \mu \mathrm{L}$ citrate phosphate buffer $100 \mathrm{mM} \mathrm{pH} 6.0,250 \mu \mathrm{L}$ chitin $1 \%$ (w/v) and $100 \mu \mathrm{L}$ of sample. The reagents were incubated at $50{ }^{\circ} \mathrm{C}$ for 10 minutes. After this period, the reaction was stopped by adding $500 \mu \mathrm{L}$ of DNS reagent (Miller, 1959). The tubes contents were heated for 5 minutes in a boiling water bath, and then $1 \mathrm{~mL}$ of water was added to each test tube. The absorbance readings were performed at $540 \mathrm{~nm}$ with the aid of a spectrophotometer. Enzymatic activity measurements were performed in triplicate. One protease unit (U) was defined as the amount of enzyme required to release $1.0 \mu \mathrm{g}$ of tyrosine per minute under the assay conditions.

\subsection{Electrophoretic analysis}

A polyacrylamide gel electrophoresis (SDS-PAGE) $10 \%(\mathrm{w} / \mathrm{v})$ was performed to proteic analysis (Laemmli, 1970). The electrophoresis was performed at $80 \mathrm{~V}$, the gel was stained with a Coomassie Blue R-250 solution (ethanol 50\% (v/v), acetic acid 10\% (v/v), and Coomassie Blue R-250 0,1\% (w/v)) during 2 hours, and then it was discolored with a solution composed by ethanol $50 \%(\mathrm{v} / \mathrm{v})$ and acetic acid $10 \%(\mathrm{v} / \mathrm{v})$ until the bands visualization.

\subsection{Nematicidal assay}

Pure population of Meloidogyne incognita was collected in Lavras, Minas Gerais, and it was identified by analysis of esterase phenotypes (Carneiro and Almeida, 2001). The nematodes were cultivated in soybean plants during 60 days, and then the plants root system was transferred to a Baermann funnel for hatching eggs and obtaining second stage juveniles $\left(\mathrm{J}_{2}\right)$, which were quantified in Peters' chamber. Solutions containing the nematodes were calibrated to $50 \mathrm{~J}_{2} / \mathrm{mL}$.

The free-living nematodes Panagrellus redivivus were cultured in a dark room into Petri dishes containing distilled water and oat bran for seven days, at room temperature $\left(25^{\circ} \mathrm{C}\right)$. Before the assay, the nematodes were extracted with a Baermann apparatus and collected in hemolysis tubes after decanting.

For each nematode species, two groups were formed in sterile tubes, one treated group and one control group. Eight replicates were performed for each group, and about 50 juveniles were poured into sterile tubes with $20 \mu \mathrm{L}$ of the extract containing $S$. grantii proteases. The control group contained the same number of juveniles in the presence of the denatured enzymes (by boiling). The sterile tubes were incubated at $28^{\circ} \mathrm{C}$ in the dark for 24 hours. After that period, the number of live $P$. redivivus and $M$. incognita 
juveniles present in each tube of the treated and control groups was counted by means of optical microscopy, according to the modified methodology described by Sufiate et al. (2017b). The data obtained in this assay were statistically interpreted by analysis of variance at significance levels of 1 and 5\% probability. Efficiency of the destruction of $P$. redivivus and $M$. incognita in relation to the control was evaluated by the Tukey test at the $1 \%$ probability level. Subsequently, the average reduction percentage of the juveniles was calculated according to the following equation:

$\%$ Reduction $=($ Mean of juveniles in control $)-($ Mean of juveniles in treatment) $\times 100$

(Mean of juveniles in control)

\section{Results and Discussion}

S. grantii latex protease activity was verified in the clear supernatant. The following values of enzymatic activity were observed: $530 \pm 46 \mathrm{U} / \mathrm{mL}$ for proteases and 0 for chitinases. Thus, although several plant latex exhibit high amounts of chitinase, in the case of the present $S$. grantii samples, there was no chitinase activity. On the other hand, proteolytic activity was measured in abundance. In addition, the presence of $34 \mathrm{kDa}$ latex glycoprotein (LGP) serine protease (Rajesh et al., 2006) has been suggested by SDS-PAGE (Laemmli, 1970) (Figure 1). However, the two-serine proteases from $S$. grantii latex isolated by Menon et al. (2002) were not detected.

A number of studies have demonstrated the nematicidal effect of latex proteases from plants (Badgujar and Mahajan, 2013; Stepek et al., 2007; Sufiate et al., 2017b). However, this is the first report on nematicidal effect of $S$. grantii. Nematicidal activity of the concentrated proteases from $S$. grantii was analyzed in vitro on Panagrellus redivivus and Meloidogyne incognita juveniles. The results show that there was a significant difference $(p<0.01)$ between the treated and control groups. In addition, it was demonstrated that the nematicidal action occurred due to the action of the proteases, since the control was only differentiated from the treatment by the presence of the enzymes with biological activity.

The analysis of the nematode reduction percentage showed a high efficiency of the proteases present in $S$. grantii latex, with $100 \%$ reduction of $M$. incognita and $72 \%$ average reduction of $P$. redivivus, compared to the control. P. redivivus is free-living nematode usually used as a model in environmental and enzymatic studies (Braga et al., 2012). These results suggest that $P$. redivivus is a great model, with greater resistance to proteases than $M$. incognita, probably due to cuticle composition differences. However, it was observed that in the case of $M$. incognita, the juveniles remained immobilized, even after the enzyme removal. On the other hand, in the case of $P$. redivivus, the juveniles were destroyed, with visible damage to the cuticle (Figure 2).

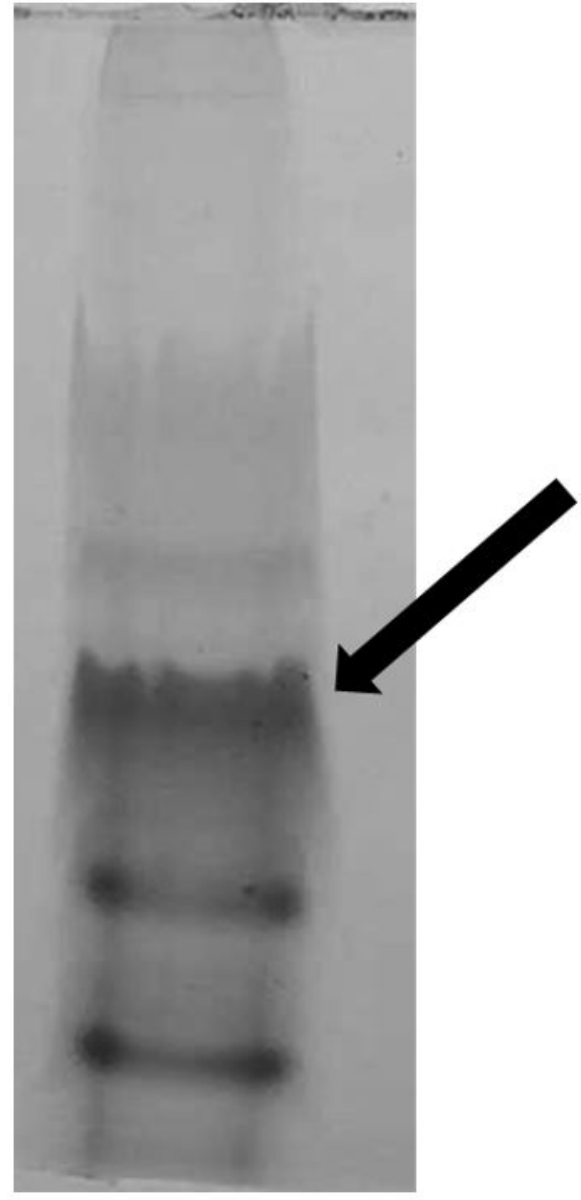

Figure 1. Proteic analysis by means of SDS-PAGE $10 \%$. The presence of $34 \mathrm{kDa}$ latex glycoprotein (LGP) serine protease (black arrow).

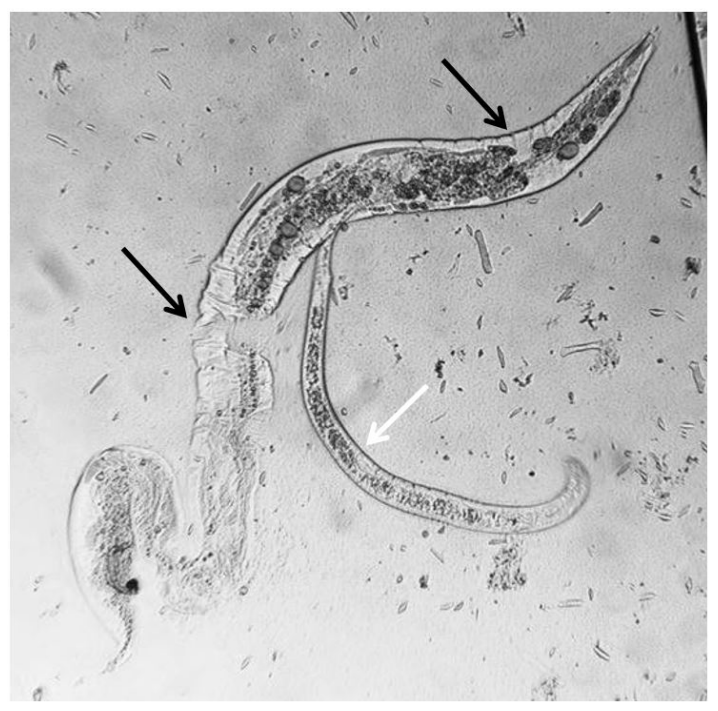

Figure 2. Panagrellus redivivus adult larvae destroyed (black arrow) after previous contact with latex proteases of Synadenium grantii. Intact juvenile of $P$. redivivus (white arrow). Light microscope, $10 \times$ objective. 


\section{Conclusion}

S. grantii latex has a myriad of traditional uses. However, latex proteases nematicidal effect was unknown until now. Altogether, our results suggest that the nematicidal action from $S$. grantii latex occurred due to the action of proteases. Thus, $S$. grantii proteases must be studied on future works regarding this use on human and plant parasites.

\section{Acknowledgements}

The authors thank FAPEMIG, CNPq, CAPES and Agiel for financial support.

\section{References}

AGRIOS, G.N. 2005. Plant pathology. 5th ed. Burlington: Elsevier Academy, 922 p.

ARAÚJO, L.A., MELO-REIS, P.R., MRUE, F., GOMES, C.M., OLIVEIRA, M.A.P., SILVA, H.M., ALVES, M.M. and SILVAJÚNIOR, N.J., 2017. Protein from Hevea brasiliensis "Hev b 13" latex attenuates systemic inflammatory response and lung lesions in rats with sepsis. Brazilian Journal of Biology $=$ Revista Brasileira de Biologia, vol. 78, no. 2, pp. 271-280. http://dx.doi. org/10.1590/1519-6984.06316. PMid:28793032.

BADGUJAR, S.B. and MAHAJAN, R.T., 2013. Characterization of thermo- and detergent stable antigenic glycosylated cysteine protease of Euphorbia nivulia Buch.-Ham. and evaluation of its ecofriendly applications. The Scientific World Journal, vol. 2013, pp. 1-12. http://dx.doi.org/10.1155/2013/716545. PMid:24348183.

BENMERACHE, A., ALABDUL MAGID, A., LABED, A., KABOUCHE, A., VOUTQUENNE-NAZABADIOKO, L., HUBERT, J., MORJANI, H. and KABOUCHE, Z., 2017. Isolation and characterization of cytotoxic compounds from Euphorbia clementei Boiss. Natural Product Research, vol. 31, no. 18, pp. 2091-2098. http://dx.doi.org/10.1080/14786419.201 6.1277345. PMid:28068859.

BRAGA, F.R., ARAÚJO, J.V., SOARES, F.E.F., ARAUJO, J.M., FERREIRA, S.R. and QUEIROZ, J.H., 2012. Use of statistical tools in the study of the conditions of predation of Duddingtonia flagrans versus Panagrellus sp. Biocontrol Science and Technology, vol. 22, no. 5, pp. 559-565. http://dx.doi.org/10 $.1080 / 09583157.2012 .670198$

BRAGA, F.R., SOARES, F.E., GIUBERTI, T.Z., LOPES, A.C., LACERDA, T., AYUPE, T.H., QUEIROZ, P.V., GOUVEIA, A.S., PINHEIRO, L., ARAÚJO, A.L., QUEIROZ, J.H. and ARAÚJO, J.V., 2015. Nematocidal activity of extracellular enzymes produced by the nematophagous fungus Duddingtonia flagrans on cyathostomin infective larvae. Veterinary Parasitology, vol. 212 , no. 3-4, pp. 214-218. http://dx.doi.org/10.1016/j. vetpar.2015.08.018. PMid:26319197.

BRAND, D., SOCCOL, C.R., SABU, A. and ROUSSOS, S., 2010. Production of fungal biological control agents through solid state fermentation: a case study on Paecilomyces lilacinus against root-knot nematodes. Micologia Aplicada International, vol. 22 , pp. $31-48$

CARNEIRO, R.M.D.G. and ALMEIDA, M.R.A., 2001. Técnica de eletroforese usada no estudo de enzimas dos nematóides de galhas para identificação de espécies. Nematologia Brasileira, vol. 25 , pp. $35-44$.
DOMSALlA, A. and MELZIG, M., 2008. Occurrence and Properties of Proteases in Plant Latices. Planta Medica, vol. 74, no. 7, pp. 699-711. http://dx.doi.org/10.1055/s-2008-1074530. PMid:18496785.

KWOK, O.C.H., PLATTNER, R., WEISLEDER, D. and WICKLOW, D.T., 1992. A nematicidal toxin from Pleurotus ostreatus NRRL 3526. Journal of Chemical Ecology, vol. 18, no. 2, pp. 127-136. http://dx.doi.org/10.1007/BF00993748. PMid:24254904.

LAEMMLI, U.K., 1970. Cleavage of structural proteins during the assembly of the head of bacteriophage T4. Nature, vol. 227, no. 5259, pp. 680-685. http://dx.doi.org/10.1038/227680a0. PMid:5432063.

MENON, M., VITHAYATHIL, P.J., RAJU, S.M. and RAMADOSS, C.S., 2002. Isolation and characterization of proteolytic enzymes from the latex of Synadenium grantii Hook, 'f'. Plant Science, vol. 163, no. 1, pp. 131-139. http://dx.doi.org/10.1016/S01689452(02)00085-7.

MILLER, G.L., 1959. Use of dinitrosalicylic acid reagent for determination of reducing Sugar. Analytical Chemistry, vol. 31, no. 3, pp. 426-428. http://dx.doi.org/10.1021/ac60147a030.

MUNHOZ, A.C., MINOZZO, B.R., CRUZ, L.S., OLIVEIRA, T.L., MACHADO, W.M., PEREIRA, A.V., FERNANDES, D., MANENTE, F.A., VELlOSA, J.C.R., NEPEL, A., BARISON, A. and BELTRAME, F.L., 2014. Chemical and pharmacological investigation of the stem bark of Synadenium grantii. Planta Medica, vol. 80, no. 6, pp. 458-464. http://dx.doi. org/10.1055/s-0034-1368300. PMid:24687740.

RAJESH, R., NATARAJU, A., GOWDA, C.D.R., FREY, B.M., FREY, F.J. and VISHWANATH, B.S., 2006. Purification and characterization of a $34-\mathrm{kDa}$, heat stable glycoprotein from Synadenium grantii latex: action on human fibrinogen and fibrin clot. Biochimie, vol. 88, no. 10, pp. 1313-1322. http://dx.doi. org/10.1016/j.biochi.2006.06.007. PMid:16997451.

STEPEK, G., CURTIS, R.H.C., KERRY, B.R., SHEWRY, P.R., CLARK, S.J., LOWE, A.E., DUCE, I.R., BUTTLE, D.J. and BEHNKE, J.M., 2007. Nematicidal effects of cysteine proteinases against sedentary plant parasitic nematodes. Parasitology, vol. 134, no. Pt 12, pp. 1831-1838. http://dx.doi.org/10.1017/ S0031182007003289. PMid:17640402.

SOARES, F.E.F., QUEIROZ, J.H., ARAÚJO, J.V., QUEIROZ, P.V., GOUVEIA, A.S., HIURA, E. and BRAGA, F.R., 2015. Nematicidal action of chitinases produced by the fungus Monacrosporium thaumasium under laboratorial conditions. Biocontrol Science and Technology, vol. 25, no. 3, pp. 337-344. http://dx.doi.org/10.1080/09583157.2014.979133.

SUFIATE, B.L., SOARES, F.E.F., MOREIRA, S.S., GOUVEIA, A.S., MONTEIRO, T.S.A., FREITAS, L.G. and QUEIROZ, J.H., 2017a. Nematicidal action of Pleurotus eryngii metabolites. Biocatalysis and Agricultural Biotechnology, vol. 12, pp. 216-219. http://dx.doi.org/10.1016/j.bcab.2017.10.009.

SUFIATE, B.L., SOARES, F.E.F., ROBERTI, A.S. and QUEIROZ, J.H., 2017b. Nematicidal activity of proteases from Euphorbia milii. Biocatalysis and Agricultural Biotechnology, vol. 10, pp. 239-241. http://dx.doi.org/10.1016/j.bcab.2017.03.014.

UPADHYAY, R., 2011. Plant latex: A natural source of pharmaceuticals and pesticides. International Journal of Green Pharmacy, vol. 5, no. 3, pp. 169-180. http://dx.doi.org/10.4103/0973-8258.91222. 